Available online http://jurnal.unimed.ac.id/2018/index.php/JLTUnimed

\title{
STEREOTYPED LANGUAGE ABOUT WOMEN ON INTERNET MEMES OF MEME COMIC INDONESIA (A Multimodal Critical Discourse Analysis)
}

\author{
Ayu Lestari Siregar \\ Busmin Gurning \\ Didik Santoso
}

Diterima Mei 2018; Disetujui Juni 2018; Dipublikasikan Agustus 2018

\begin{abstract}
This study examined 21 (twenty one) Internet memes taken from instagram wall of Meme Comic Indonesia (MCI). This studies applied Multimodal Critical Discourse Analysis promoted by Van Leeuwen which particularly in this study was the merger between Three Dimensional of Fairclough and Visual Grammatical of Kress and Van Leeuwen. The results of this study revealed five kinds of stereotyped language about women which are women's personality traits, women's cooking domestics behaviour, women's physical appearances, women's teaching occupation and women's driving motorcycle behaviour which considered as new kind of stereotype about women. It is also revealed that the process of realization of stereotyped language about women is by seeing the context of the features used by the creator of the internet memes. The reasons of using stereotyped language about women as humour can be seen as critics and warning attemptions by the creator of the internet memes.
\end{abstract}

Key words: Stereotyped Language about Women, internet memes, Multimodal Critical Discourse Analysis

How to Cite: Ayu Lestari Siregar (2018).Stereotype Language About Women on Internet Memesof MemeComic Indonesia (A Multimodal Critical Discourse Analysis). Jurnal Linguistik Terapan Pascasarjana Unimed, 15 (2): 102-112 


\section{INTRODUCTION}

Meme Comic Indonesia (MCI) claimed that the site was the largest site of Internet Meme in Indonseia. Based on the wall biography observed at April 2017, this site has overthreee million followers on instagram. The objective of Meme Comic Indonesia in spreading internet memes was merely for fun as what written on the short biography. This was fit to Shiftman (2014 :2) suggested that internet meme was used as propagation of items such as jokes via the internet. Despite of Shifman's argument about spreading jokes and ment for fun, in reality the writer identified Internet memes created by Meme Comic Indonesia (MCI) has gaining such protests from women those who got offended by the stereotypes content of the jokes.

In such stereotyped point of view, women were associated with personality traits such as nagging, talkactive, pussy, or sensitive (Brannon, 2004). Appearently the internet memes of MCI are also contain stereotyped language about women. For example see the following Internet taken from the instagram wall of MCI.

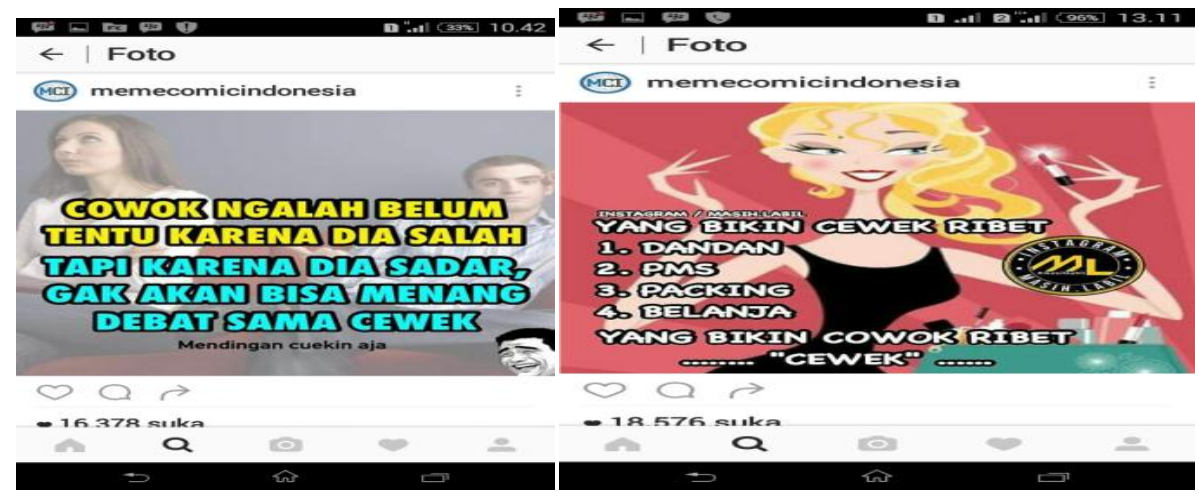

These memes have resulted some protests which failure the entertaining purpose. Clarapleter08 write; "Gak gtu jglah coeg" (not even close) and also Nurnur_nurul writes, "jelek amat cewek di mata cowok sampe kek gitu," (surprisingliy that's how bad is woman in man's view) as their disagreement and dissappointement toward the memes which indicate negative stereotypes.

There were four categories of women stereotypes by Deaux and Lewis (1984); personality traits, domestics behaviors, occupations, and physical appearance. However, there is one addition on women stereotyped existed on Internet meme of MCI. The memes about women's riding motorcycle behavior was the addition the writer proposed.
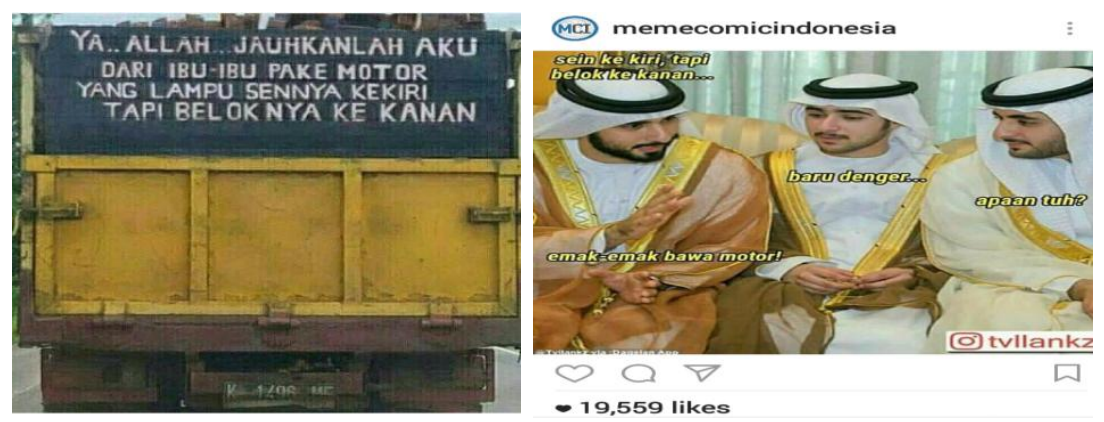

There were numbers of memes which keep portraying wreckless behavior of women on the street. For example, the common assumptions that women, particularly mothers were those riders who 
put the light sign on left but turn to the other side of street. The writer would like to conduct this study in order to find out what kinds of stereotypes exist on internet memes of MCI.

The awarness of women on negative stereotypes over them was a good start as Lazar (2005) demands on women's unity in fighting any discrimination againt their gender. However, this study did not only rely the identification of stereotyping based on negative comments on MCI posts. There were still emerge of linguistics analysis to reveal how exactly the form of stereotypes on internet memes of MCI.

In this study, the writer of this research proposed to conduct the analysis by using Multimodal Critical Discourse Analysis. Multimodal Critical Analysis was a merger of two distinct fields of applied linguistics: critical discourse analysis and multimodality (Van leeuwen $2013: 1598$ ).

Further Van Leewen (2013) admits unlike Critical Discourse Analysis and Multimodal analysis, Multimodal Critical Discourse Analysis was still on the minor work. There was less attention to this diciplinary. The writer would like to contribute this research as the attention to the less presence of multimodal analysis in critical stance.

In addition, there was need to do critical analysis on both visual and verbal language on a single text which relies on burried ideology and revealing the hidden from the surface (Machin and Myer, 2012). Especially since the emerge of the internet (Van Leeuwen, 2013).

Particularly in this study, the analysis of internet memes could only done by both examined what was written and depicted and also the missing part on the internet memes. That was the reason of the writer adopted this kind of data analysis.

The writer proposed to conduct the analysis by using Fairclough Three Dimensional Critical Discourse Analysis on linguistics features of memes. The writer resfectifully considers the other Critical Discourse anlysts such as Van Dijk (2008) who relies analysis on the dominant and inequality, and also Meyer (2004) who demands advocatery on doing CDA.

However, Fairlclough framework was the most prominent analysis to this study. Stereotype is about attributing traits and expectancies towards member of group attached. Fairclough framework itself specifies the linguistics description about the kind of attribution attached to each participants in the discourse. In addition, stereoype is the part of Social Psychology field. This dicipline could be studied from applied linguistics persfectives particularly CDA (McGarty and McVitty, 2008).

Critical Discourse Analysis (CDA), McGarty and McVitty argue, was the analysis of discourse with emphasis on power and ideology, which has the similarity to what Fairclough (1989) proposed which also linked to the ideological effect.

In addition, the writer of this research also proposed to use Visual Grammar Analysis by Kress and Van Leeuwen in analysing the images. This is because it has the closest similarity to Fairclough framework. Kress and Van Leeuwen, and Fairclough shared the same persfective in defining language as the process of making meaning and it can be seen from the use of Halliday Functional Grammar in both of their analysis processes. 
One study which have the most prominent similarity on the way of analyzing data comes from Vahid and Esmae'li (2012) entitled "The power behind images: Adverstisement Discourse in Focus."

They used both Fairclough Three Dimensional Critical Discourse Analysis and Kress and Van Leeuwen Visual Grammar Analysis in analyzing advertisement. However, this research missed the concept of Multimodal Critical Discourse Analysis has introduced by Mayr (2004) since the application was there, yet the name of field was unmentioned.

The other study was by Hoon (2011), “Celebrating Singapore's Development: An Analysis of the Millenium Stamps". The study examines the millenium stamps issued by Singapore govermet. This study highlighted the over/official construction of Singapore's notion building with a view of unpacking the ideological messages underlying the construction. Hoon also doing CDA by Fairclough framework, and separated the analysis from the visual. Unfortunately, there was no any clear way of analyzing image served on her paper.

In addition, Monson, Donaghue, and Gill (2016) work on, "Working Hard on the Outside: A Multimodal Critical Discourse Analysis of the Biggest Looser Australia," in studying the TV show. However, less attention on the linguistics features on their analysis which should be count as well.

Study on Internet memes, for example, research by Bozkus (2016) studied on, "Pop Polyvocality and Interent Memes: As a Reflection of Socio - Political Discourse of Turkish Youth In Social Media," Also by Milner (2013) in his study "Pop Polyvocality: Internet memes, Public Participation, and the Occupy Wall Street Movement,"

The similary of these two researches were they placed Internet memes as alternative power againts injustice and discrimination. On the other hand, the writer did the vice verse of the previous research. since it was the internet memes which portraying injustice such stereotyping, and there was a willingness to reveal the practice.

In addition, Lidya (2016) on her study, "Stereotyping padaJombloSebagaiHasilKonstruksiKreator Meme di Instagram (Analisis Textual pada Meme di AkunInstagramMemecomic Indonesia.

This study revealed eight kinds of stereotyping on Internet memes in Meme Comic Indonesia (MCI) instragram, which led to mocking, insulting, and put "jomblo" or single person on the corner and caused cyberbullying. This study conducted by Lidya has the closest theme with the research on proposed, which is about stereotyping issue on Internet memes of Meme Comic Indonesia(MCI).

However, it still needed to study this topic since the previous researches were studied from communication sience perspective. Less attention to the linguistics and images features that exclusively done in applied linguistics.

It could be seen the presence of studies about stereotyping, Internet memes, and also the application of Multimodal Critical Discourse Analysis. However, there is still need work on studying Stereotyped language about women on Internet memes analyzed by Multimodal Critical Discourse Analysis. 


\section{RESEARCH METHOD}

This research conducted in qualitative content analysis. Qualitative content analysis is a method for systematically describing the meaning of qualitative data (Schreier, 2012). In addition, Mayring (2014) state that Qualitative content analysis is undersood as a rule guided research process.

This reseach adopted the method of qualitative content analysis method of Mayring (2014) as follows:

1. Decided concrete research question. The researcher decided to covers the research questions on what, how, and why in order to describe the kinds of stereotyped language about women and elaborate the realization and further explain the context of realization.

2. Linked researh question to theory (state of art, theoritical approah, perconceptions for interpretations). The researcher provided theories from rellevants experst in order to provide the temporary answers toward the research questions.

\section{FINDINGS AND DISCUSSIONS}

The following findings are the results toward the applications of Multimodal Critical Discourse Analysis within the 21 internet memes of Meme Comic Indonesia:

1. It is found that memes of Meme Comic Indonesia (MCI) contain stereotyped language about women on internet memes of MCI. Those kinds of stereotyped language invested in 5 (five) categories; they are women's personality traits which are tempramental during PMS, slow or less credible about time, and aggresives; women's physical appearance, women's domestics behaviour, women's occupations, and women's driving attitude. These categories are identified by using description stage of analysis to identify the fourth level of language abstraction (stereotyped language level) which consist of descriptive action verb, interpretative action verb, state verb, and adjectives. In addition, the participant or the target of specification and the specifics terms is also used in identification whether the meme convey stereotyped language about women.

2. The way of realization of stereotyped language about women on internet memes of MCI can be seen from the interpretatation stage of analysis. This stage is done by interpretating the context, topic, and point of the memes based on the features used on it. It is found that the words, phrases, clauses and conversation in the memes are dominated by declarative modes. In this study, the used of declarative moods can be seen as the claim that stereotyped language about women is true and the viewers are forced indirectly to believe it. There are 8 Carrier participants in the meme, and the Carriers' gender is female. The clause are directly point out that the attributes about the personality traits are carried by women. The kinds of Circumstance like the Circumstance of Location, for woman, in this world, in the market,' serve the limitation to whom or when specifically the statement or the claim occured. From the semantics feature, there is 2 metaphor and 3 antonym found. The metaphor is about comparing women's traits with unrealistics comparison. From the 
cohesive features, there are 14 conjuctions found. The conjuctions are functioned to connect the lines of the clause which majorly are separated by the image or non verbal source. The aggressives represent participants from the multimodal source is the non verbal source. This choise of aggressives represent participants are ment for to catch the eyes of the viewers and let them be intrested by the provocative or odd images so that the viewers will pay attention to the meme.

3. In the explanation stage, the analysis is about to uncover the social determinants (social relations), the ideology, and the effect of discource. Particularly to this study, the social relations are majorly between women and the rest of the world, wich determined by the ideology or the stereotyped judgements towards them, and resulted the various effect toward themselves. These identification resulted the reason of the realizations of stereotyped language about women. There are two possible reason to have stereotype judgement about women in humour, they are for power initiation or punishment. This point of view seeis the woman is the dominated one and the stereotyped language about them is the consequence of their weakness. However particularly in this study, the humour by using such stereotyped language about women are more like portraying the women is the aggressives one. It can be seen from the purpose of the meme, whih more like about warning, and rewarding instead of about power initiation or punishment. Women are the aggressives creatures in this era and the warn are ment for the world who must be carefull during the interracation with them, for example the personality traits of women during and after her period. And also, women are the aggressives ones in the social practice exist in the family and they are rewarded for their aggressiveness. For example the compliment that woman who helps their parents are rewarded by the compliment of such beatiful lady. So, it is conclude that instead of power initiation and punishment, the context of the realizations of stereotyped language about women is more than ment for warning to the other, and reward for women themselves.

After arranged the findings, there are some points of the findings need to be discussed as the improvement or rejections towards the theories or previous researchs drawn.

\subsubsection{Stereotyped Language about Women's Driving Motorcycle Behaviour}

Women's driving motorcycle behaviour consider as the new kind of stereotyped language about women because this is unfit to the four kinds women's stereotypes by Deaux and Lewis (1984). The way it is proven as stereotyped language about women can be seen from the realization and the context of the claim. The particular vehicle is the motorcycle and the specific action done by those women is related to the light sign.

This new finding considered to improve the previous study by Lidya (2016) in revealing the kinds of stereotypes on internet memes of Meme Comic Indonesia (MCI). While Lidya's work highlight the stereotyped language towards jomblo 'single' people, this study more likely to highlight the other target of stereotyping which are women. 
From a stereotyped language, it can be rooted to the language abstractions (Semin and Freidler 2002) which are descriptive action verb. In addition, the three of women stereotypes kinds each contributed in order creating the new stereotyped language about women. First is from the domestic behaviour aspect, mothers tend to use motorcycle to buy grocery or pick up their children. Second is occupation, mothers are now drive motorcycle so that they can get to their workplace by their own. Third is personality traits, mothers as women as well has casted as rattle brained or plip up so that they tend to confuse the light sign whether it is right or left. So it means that, the combination of more than one stereotype will resulted the whole new kind of stereotyped, which is contrast to Brannon (2005) argument who only limited that stereotype about domestic behaviour is the one which affected the occupation provided to women.

If it is related to the location of this research, there is an implication which might need to be discussed. Women in Medan in this context tend to communicate in such challenging way. In the moment they decide to go, they might say not to go or otherwise 'yes' could be ment 'no.' It means that, this kind of behaviour could drive men involved with the women mad. The men get confused to what is really the women want since the women right is left and their left is right or even worse, their left or right perhaps are straight.

\subsubsection{Women's Aggressive Personality Traits Related to Parenthood Role}

Women's aggressive personality trait is contrast with submissive personality traits suggested by Archer and Llyod (2004). It has been believed that women are naturally submissive which means that they ideally obey others, calm, or weak. However it is found that women can be aggressive related to their parenthood role.This might contrary with the previous study by Zhang and Jamil (2015) which found that the way women portrayed in newspaper tend to be soft and weak. Appearantly from the persfective of internet memes' creator, women are tend to be hard and aggressive. However, the source of data might be considered as the differences caused.

When it comes to practice the social roles, women are parents who rule and run the domestics activities in the way they love to. For example in taking care of children, it is known that mother is the one who responsible to give punishment to children, as the power initiation in a family. In addition, in fulfilling the grocery, mother can become such a tricky bargainer that able to push the seller to the lowest price. Also, the traits of being grumpy, stern, and fussy that make women take domination in talking are associate with their future role as mother. It means that, when a social role of a woman exchange, instantly become a mother, she tend to gain some power and dominance related to her domestics role. She can be such pusher and being dominant in the way she does her roles. Women do not ultimately change into dominant but in particular circumstance, they are dominant and the rest of society member goes with their rules. Secondly, Women's time management category infer one additional personality traits associate with women which is slow personality traits. 
Archer and Llyod (2004) list of category does not include slow personality traits of woman. However it is found that women are cast being slow and disable to manage their time which tend to give trouble to anyone who are waiting for them. This kind of stereotype is associated with domestics role of women. For example in doing the grocery, if man is the one who drives then the woman is the one who go inside the market in fulfilling it. The man barely do nothing but simply wait. This is then resulted the idea that women tend to be slow because men who are waiting for them get bored and believe that women take more time then they actually need.

\subsubsection{The Reasons of Using Stereotyped language about Women as Humour}

Warning and Critics considered as reasons of using stereotyped language about women as humour material. The humour about women are therefore set as punishment and power initiation toward women (Chamber 2005). However it is found that instead of punisment and power initation by men to women, the humour on internet memes of MCI are more likely as warning toward men about women themselves.

This finding has the similarity to the previous study by Bozkus (2016) which portrayed internet memes as the media of spreading the critics and warning that placed the social determinant bellow the radar or what so called hiding behind the jokes or humour. However, this might seems contrary with the study from

This happens because the memes depicted that women are missed from the specification, and the expectations. First example women's role specification is to cook and to be dressed well. However, Women are depicted as the one who more care about get dressed well instead of cook. It happened because women's opportunities are now widely opened in the field of men. Women can compete with men in engineering, law, or politics.

They might seem their beauty as power it self so they tend to improve their beauty. Whatsoever the expectation still remain the same so that it is negletted and resulted the idea that women are now care about get dressed instead of cooking.

\section{CONCLUSIONS}


This study has done in such deliberately way. It is now to conclude the result of this study as follows:

1) There are five kinds of stereotyped language about women on internet memes of Meme Comic Indonesia (MCI). They are women's personality traits, women's physical appearances, women's domestics behaviour, women's occupation, and women's behaviour in driving motorcycle.

2) The process of realization of stereotyped language about women on internet memes of MCI by the creators of the memes done by selecting the features both verbal and non verbal. It could be words, phrases, or clauses. And it could be rage comics or reactions photoshops. Then the development of frame, scripts, ans schemata which resulted the topic and the point of internet memes under the expectation of the social determinants in spreading the ideology about women and the effects might resulted from them.

3) The context or the reasons of the realization of stereotyped language about women on internet memes of MCI are therefore as warning or critics as the manifestation of the expectation, specification, and belief about women's attidude, behaviour, traits, and activities associated with women.

\section{REFERENCES}

Archer, J. and Llyod, B.B.2002. Sex and Gender. 2nd Ed. Cambridge: Cambridge University Press

Asmarawan A M.S. 2015. Analisis Isi Pesan Permasalahan Sosial dalam Internet Memes, Journal research. 2015.

Bozkus S.B.2016. Pop Polycality and Internet Memes: As Reflection of Socio-Political Discourse of Turkish Youth in Social Media. Global Media Journal TR Edition.

Brannon, L (2005), Gender and Stereotype: Psychological Perspective, London: Pearson

Brown P.M. 2004. The Role of Theories in the Formation of Stereotype Context in Stereotypes as Explanation. The Formation of Meaningful Beliefs about Social Groups. Ed by McGarty C, Cambridge : Cambridge University Press, pp. 67 - 89

Chamber. D. 2005. Comedies of Sexual Morality and Female Singlehood, in Beyond a Joke: the Limits of Humour. Ed. by Lockyer, S. New York: Palgrave Macmillan

Dixon J. 2012. Beyond Prejudice; Extending the Social Psychology of Conflict, Inequality and Social Change. Cambridge: Cambridge University Press

Fairclough, N. 2001. Language and Power. New York: Longman.

Fairclough, N. 2003. Textual Analysis for Social Research. London: Routledge

Feist, J. 2016. Semantic Structure in English. Amsterdam: John Benjamin

Gerber, G.L. 2008. Status and the Gender Stereotyped Personality Traits: Toward an Integration. New York: Springer 
Halliday, M.A.K. 2014. Halliday's Introduction to Functional Grammar. London: Routledge

Hoon, CH. 2004 Celebraring Singapores' Development: An Analysis of the Millenium Stamps in Systemic Functional Linguistics and Critical Discourse Analysis: Studies in Social Change. Ed by Young, L. and Harrison C. New York: Continuum

Hua, C. 2013. Critical Discourse Analysis of Woman Language at the lexical Level in Sense and Sensibility. Vol.4 No.2: www. Journals. Savap. Org. Pk.

Kennedy, G. 2003. Structure and Meaning in English. Malysia: Pearson

Kreidler, C.W. 2002. Introducing English Semantics. London: Taylor and Francis E Library

Kress. G, 2006. Reading Images: The Grammar of Visual Design. New York: Routledge

Lazar, M. 2007. Feminist Critical Discourse Analysis: Articulating a Feminist Discourse Praxis. London: Routledge.

Lee, T.L. 2008. Stereotype in International Encyclopedia of the Social Sciences second Edition, Ed by Darity, William A Jr. New York: Macmillan

Lidya. 2016. Stereotype pada Jomblo sebagai Hasil Konstruksi Kreator Meme di Instagram. (Analisis Textual pada Meme di Akun Instagram MemecomicIndo). A research journal.

Lockyer, S. 2005. Beyond a Joke: the Limits of Humour. New York: Palgrave MacMillan

Machin, D. (2012), How to Do Critical Discourse Analysis, A Multimodal Introduction, London: Sage

Marco, L. 2005. Linguistic Choises for the Representation of Women in Discourse. www.raco.cat

Mayring, P. 2014. Qualitative Content Analysis: Theroretical Foundation, Basic Procedures, and Software Solution. Klagenfurt: Gesis

Mckinlay, A. 2008. Social Pshychology and Discourse. West Sussex: Wiley Blackwell

Miller, J. 2002. An Introduction to English Syntaz. Ediburgh: Dediburgh University Press

Monson, O. 2016. Working Hard on the Outside: A Multimodal Critical Discourse Analysis of the Biggest Looser Australia. Routledge: Journal of Semiotic DOI: 10.1080/10350330.2015.1134821

Murray, M. 2005. The Law of Father? Patriarchy in the Translation from Feudalism to Capitalism. New York: Taylor and Francis e - libarary

O'Halloran. K. 2011. Critical Discourse Analysis in The Routledge Hanbook of Applied Linguistics. Ed. By Simpson J. New York: Routledge. Pp $445-459$

Rastic, A. 2014. New Language Media: Interne Memes Manuscript. University Journal of Infromation Technology and Economics: hhtp://www.unite.edu.rs/

Saeed, J.I. 2003. Semantics. Second Edition. Oxford: Blackwell

Semin, G.R.2008. Stereotypes in the Wild in Stereotype Dynamics Language-Based Approaches to the Formation, Maintanance, and Transformation of Stereotypes. Ed by Kashima Y. New York and London: Lawrence Erlbaum

Schensul, J. 2008. What Research Methodology is not in The sage Enclyclopedia of Qualitative Research Methods. Vol. 1 and 2. Ed by Given, L,M. California: Sage. 516 - 521. 
Schreiber, JB. 2008. Data in The sage Enclyclopedia of Qualitative Research Methods. Vol. 1 and 2. Ed by Given, L. M. California: Sage

Scollon, R. 2003.Language in the Material World. New York: Routledge

Shiftman, L. 2014. Memes in Digital Culture. Massachusets: MIT Press.

Solway, K. 1995. Woman and It I Unwise to Know about Her.bookforyou.org

Unsworth, L. 2008. Multimodal Semiotics: Functional Analysis in Context of Education. Norfolk: Continuum

Spears R. 2004. Four Degrees of Stereotype Formation: Differentiatiing by any Means Necessary in Stereotypes as Explanation. The Formation of Meaningful Beliefs about Social Groups. Ed by McGarty, C. Cambridge: Cambridge University Press, pp. 127- 156

Vahid, H., 2012, The Power Behind Images: Advertisement Discourse in Focus, International Journal of Linguistics, Vol. 4, No. 4,pp. 36 - 51

Van Dijk, T. 2008. Discourse and Power. China: Palgrave Macmillan.

Van Leeuwen, T. 2013. Critical Analysis of Multimodal Discourse In The Encyclopedia of Applied Linguistics, Ed by Chapella C. A.

Wahyuningtyas, 2006. Stereotip Gender dan Dominasi Kapitalis Dalam Iklan Televisi: Suatu Analisis Wacana Kritis terhadap Iklan Televisi Citra Korporasi Gudang Gram di Bulan Ramadhan. Vol.4. No.1. HUMANIORA

Wenneker, C. 2004. A Model of Biased Language Used in Stereotype in Stereotype Dynamics Language Base Approach to the Formation, Maintenance, and Transformation of Stereotype. 2008. Ed by; Kashima, Y. New York: Lawrance Earlbaum Associates, pp 165 -188

Wodak, R. 2004. Methods of Critical Discourse Analysis. London: Sage

Zhang, L. 2015. Gender Inequality in Chinese News Discourse: A Critical Discourse Perspective. Vol. 5. No.2. International Journal of English Linguistics: Canadian Centre of Science and Education. 